\title{
Yarı-humid ekolojik koşullar altında oluşmuş toprakların fiziko-kimyasal ve besin elementi içerikleri ile konumsal dağılımlarının belirlenmesi
}

\author{
Arif AYDIN ${ }^{1}$, Orhan DENGİ ${ }^{\text {iD }}$ \\ ${ }^{1}$ Tarım ve Orman Bakanlığı İl Tarım ve Orman Müdürlüğü, Samsun \\ ${ }^{2}$ Ondokuz Mayıs Üniversitesi Ziraat Fakültesi Toprak Bilimi ve Bitki Besleme Bölümü, Samsun
}

Alınış tarihi: 12 Mart 2019, Kabul tarihi: 26 Eylül 2019

Sorumlu yazar: Orhan DENGIZ, e-posta: odengiz@omu.edu.tr

\section{$\ddot{0} \mathbf{z}$}

$\mathrm{Bu}$ çalışma ile Samsun ilinin güneyinde bulunan Kavak ilçesi sınırları içerisinde yer alan Seyitali, Kaya, İdrisli, Muhsinli, Beyköy ve Çayırlı mahallelerine ait toplam 1523 parselden oluşan ve 397.3 ha alan kaplayan tarım arazilerin bazı fiziksel, kimyasal ve verimlilik özelliklerinin belirlenmesi ile CBS yardımıyla farklı enterpolasyon modeller kullanarak 14 farklı parametre açısından dağılım haritalarının hazırlanması amaçlanmıştır. Alanın yıllık ortalama sicaklık $10.2{ }^{\circ} \mathrm{C}$ ve yillık ortalama yağış miktarı da 512.5 mm'dir. Newhall simülasyon modeline göre, toprak sıcaklık rejimi Mesic ve toprak nem rejimi ise Typic Xeric olarak belirlenmiștir. Çalışma sahasından 200m x 200m aralıklarla oluşturulan grit sistemden yüzey $(0-20 \mathrm{~cm})$ ve yüzey altı $(20-40 \mathrm{~cm})$ toplam 233 adet yer koordinatları ölçülerek toprak örnekleri alınmıştır. Laboratuvara getirilen topraklar, $\mathrm{pH}, \mathrm{EC}, \mathrm{CaCO}_{3}, \mathrm{OM}, \mathrm{N}, \mathrm{Ca}, \mathrm{Mg}, \mathrm{K}, \mathrm{P}$, $\mathrm{Na}, \mathrm{Fe}, \mathrm{Cu}, \mathrm{Zn}$ ve $\mathrm{Mn}$ analizleri yapılmıștır. Analiz sonuçlarına göre, toprakların tamamı tuzsuz, $\mathrm{pH}$ değerleri ise nötr-hafif alkali arasında değișmektedir. Kireç içerikleri az ve orta düzeylerde, OM ve çinko ise genel olarak yeterli olarak belirlenmiştir. Ayrıca, toplam azot, magnezyum, fosfor, demir ve mangan yeterli düzeyde bulunmuştur. Ayrıca, uygun gübreleme ve arazi yönetimi pratikleri için uygun enterplasyon model kullanılarak bu parametrelerin dağılım haritalarının oluşturulmuştur.

Anahtar kelimeler: Toprak verimliliği, enterpolasyon, CBS
Determination of physico-chemical and nutrient element content of soils formed under semihumid ecological environment

\begin{abstract}
The aim of this study was to determine some physical, chemical properties and nutrient element content of agricultural soils which cover about 397.28 ha and includes 1523 parcels of Seyitali, Kaya, Idrisli, Muhsinli, Beykoy and Çayirli neighborhoods located at Kavak district in the south of Samsun province and to create their distribution maps using interpolation models in CBS medium. The average annual temperature is $10.2{ }^{\circ} \mathrm{C}$ and the annual average rainfall is $512.5 \mathrm{~mm}$. According to Newhall simulation model, soil temperature and moisture regimes are Mesic and Typic Xeric, respectively. Total 233 soil samples coordinated were collected from soil surface $(0-20 \mathrm{~cm})$ and subsurface $(20-40 \mathrm{~cm})$ using $200 \mathrm{~m} \times 200 \mathrm{~m}$ grit system in agricultural fields. Physical (soil texture), chemical $\left(\mathrm{pH}, \mathrm{EC}, \mathrm{CaCO}_{3}\right.$ and $\left.\mathrm{OM}\right)$, and nutrient elements (TN, $\mathrm{Ca}, \mathrm{Mg}, \mathrm{K}, \mathrm{P}, \mathrm{Na}, \mathrm{Fe}, \mathrm{Cu}, \mathrm{Zn}$ and $\mathrm{Mn}$ ) analysis were done. According to results, all agricultural soils are non-saline and their reaction varied from neutral to slightly alkaline. While lime content has between low and medium level, $\mathrm{OM}$ and zinc values were determined generally sufficient. In addition, total nitrogen, $\mathrm{Mg}, \mathrm{P}, \mathrm{Fe}$ and $\mathrm{Mn}$ were determined in sufficient level. In addition, in order to make suitable fertilization and land management practices, distribution maps of all these parameters were generated using suitable interpolation model.
\end{abstract}

Key words: Soil fertility, interpolation models, GIS 


\section{Giriş}

Geçmişten günümüze insan, doğal yaşamını devam ettirebilmek için sürekli tüketmek zorundadır. Hız kesmeden artan dünya nüfusu, glda tüketimini tahmin edilemez bir şekilde artırmaktadır. Ancak günümüzde bu baskıyı artıran yalnızca beslenme ihtiyacı değildir. Tarımsal ürünlerin hammadde olarak kullanıldığı sanayi sistemlerinin gelişmesi ile beraber seri üretimlerin artması bir diğer sebeptir (Kirişçi ve ark., 1999). Tarımsal üretim yapılan alanlar artırılamadığından elde kalan alanların sürdürülebilir tarımsal üretim esaslarına uygun olarak üretim modellerinin belirlenmesi gerekmektedir. Tarımsal üretim açısından toprağın sürdürülebilir verimliliği, içerisinde gerçekleşen kimyasal, fiziksel ve biyolojik süreçlerde yer alan bitki besin elementlerinin dengesi ile de yakından ilişkilidir. Toprağın içerisinde bulunan bitki besin elementleri amenajman şekline bağlı olarak, bu süreçler içerisinde toprak verimliliğini direk veya endirekt olarak etkileyebilmektedirler.

Geleneksel tarım uygulamalarında verim artışını sağlayabilmek için çiftçiler genelde makro besin elementleri içeren gübreleri vererek elde edilecek hasadı artırmaya çalışmaktadır. Toprak özellikleri göz önüne alınmadan atadan kalma yöntemler ile yapılan gübreleme, sürüm, sulama vb. tarımsal uygulamalar geri dönüşümü çok zor sonuçlar doğurabilmektedir. Tarım topraklarının erozyon ile kaybı, çoraklaşması, sıkışması ve hatta amaç dışı kullanılması tarımsal üretim yapılabilecek alan miktarlarının git gide daralmasına sebep olmaktadır. Ülkemiz topraklarında ise bitki besin element düzeyleri genel olarak bitkilerin yararlanabileceği seviyelerin altındadır. Bu sebeple bitkisel üretim yapılırken verimi ve kaliteyi artırmak için topraktan uzaklaşan bitki besin elementinin yerine konulabilmesi amacı ile gübreleme yapılması gerekmektedir. Ancak ülkemizde kullanıma sunulan gübre içerikleri bitkiler için gerekli olan tüm besin elementlerini maalesef kapsamamaktadır (Özyazıcı ve ark., 2016). Bu sebeple gübrelemenin hassas tarım uygulamalarına uygun bir şekilde yapılabilmesi içinde toprakta bulunan bitki besin element kapsamının belirlenmesi gerekmektedir. $\mathrm{Bu}$ konuda birçok araştırma yapılmış ve toprakta bulunan bitki besin elementleri kapsamlarının toprak özellikleri ile ilişskileri ortaya konularak yerel ve bölgesel olarak oluşmuş olan sorunların çözülmesi için öneriler üretilmiştir (Adiloğlu ve Adiloğlu, 2004; Ateș ve Turan, 2015; Çakıcı ve ark.,
2012; Çimrin ve Boysan, 2006; Tarakçıoğlu ve ark, 2003; Tümsavaş ve Aksoy, 2008).

Toprak verimlilik özelliklerinin tarımsal alanlarda kısa mesafelerde dahi değișim göstermesi ve bu değişimin izlenebilme olanakları, girdi optimizasyonu sağlayan, çevreye duyarlı hassas tarım ve değişken oranlı gübre uygulamaları teknolojilerini doğurmuştur. Hassas tarım uygulamaları ile üretimde optimizasyon sağlanabilmekte, çevreye daha duyarlı tarımsal uygulamalar geliştirilebilmektedir (Güçdemir, 2006). Orta ve Doğu Karadeniz Bölgesi tarım topraklarının temel verimlilik düzeyleri ve alansal dağılımları belirlenmesi üzerine (Özyazici ve ark, 2017) yaptıkları çalışmada ise tarım alanlarını temsil edecek şekilde 2,5 x 2,5 km grid mesafelerde 0-20 $\mathrm{cm}$ toprak derinliğinden toplam 3400 adet toprak örnekleri alarak toprakların CBS yardımıyla temel bazı fiziksel ve kimyasal analiz sonuçlarına ait dağılım haritaları oluşturmanın yanı sıra Bölge topraklarının \%58,83'ünde fosfor noksanlığı görülürken, toprakların \%42,68'inde ekstrakte edilebilir potasyumun yeterli olduğunu belirlemişlerdir.

Toprakların farklı arazi kullanımları altında, bazı makro besin elementi içerikleri $(\mathrm{N}, \mathrm{P}, \mathrm{K})$ içeriklerinin konumsal dağılımlarını belirlemek amacıyla Elazığ İli Baskil İlçesine bağlı Şeyh Hasan Köyü'nde yaklaşık 400 hektar alan üzerinde bir çalışma gerçekleştirmiştir (Arslan ve ark., 2018). Yapılan bu çalışmada, 174 farklı noktadan 0-15 cm derinlikten toprak örnekleri alınarak alansal dağılımı belirlemek için 5 farklı enterpolasyon yöntemi karşılaştırarak, en iyi dağılımı veren yöntem belirlenmiş ve toplam $\mathrm{N}, \mathrm{P}_{\mathrm{av}}$ ve $\mathrm{K}_{\mathrm{av}}$ 'un konumsal dağılım haritaları hazırlanmıștır. Elde edilen dağılım haritalarına göre, çalışma alanı FAO sınıflaması dikkate alındığında toplam $\mathrm{N}$ ve $\mathrm{K}$ yönünden yeterli düzeyde belirlemişlerdir. Diğer taraftan P'ın çalıșma alanının çok az bir kısmında az düzeyde buna karşın genelde yeterli düzeyde olduğunu belirlemişlerdir.

Tüm bunlara karşılık ülkemiz toprakları üzerinde yapılması planlanan hem tarımsal açıdan hem de tarım dişı projelerin nihai hedeflerine azami yakınlığın sağlanabilmesi konuma dayalı, nitelik ve nicelik bakımından özellikleri içeren toprak veri tabanının varlığına bağlıdır (Çullu, 2012). Eğimli kırsal alanlarda oluşan topraklar çok kısa mesafelerde bile değişiklik gösterebilmektedir (Hagedorn vd, 2010). Bu sebeple yapllacak olan haritalama çalışmalarında kullanılacak modellerin 
hazırlanmasında seçilecek yöntemlerin belirlenmesi önemli bir ișlemdir. Bunun için (Keskin ve Grunwald, 2018) Regresyon Kriging (RK), dijital toprak haritacısının alet kutusundaki en popüler, pratik ve sağlam hibrit uzamsal enterpolasyon tekniklerinden biri olduğunu ve bunun yer ve zamandaki çoklu ölçeklerde toprak dağılımı modellerinin hazırlanmasında kullanıldığını belirtmiştir. RK tekniği her ne kadar tartışmalı olan bir yöntem olsa da 2004-2014 yılları arasında Amerika'nın Catena, Geoderma ve Toprak Bilimi Derneği dergilerinde 40 farklı makalede toplam 142 farklı modelde 18 ayrı değişken dahil edilerek incelenmiştir. Dünyada konumsal enterpolasyon yöntemlerinin uygulanması konularında çeşitli alanlarda yapılmış birçok çalışma bulunmaktadır (Feizizadeh ve Blaschke, 2013; Luo ve He, 2011; Mapedza ve ark., 2003; Özyazıcı ve ark., 2016; Sharma ve ark., 2008; Taşan ve Demir, 2017). Toprak verimlilik özellikleri alansal olarak değiştiğinden, örneklenmiş iki nokta arasında kalan örneklenmemiş kısımda bu iki noktadan alınan bilgilerin jeoistatistiksel istatistiki yöntemler kullanılarak tahmin edilebilmektedir. Bu tahminler için araştırmacılar uzaysal korelasyonu belirlemek amacı ile enterpolasyon ve ekstrapolasyon yöntemleri kullanmaktadırlar (Ersoy ve Yünsel, 2008). Bu örnek noktalarından elde edilmiş olan veriler bilgisayara aktarlarak konumsal enterpolasyon teknikleri ile dağıtılmak sureti ile dağılım haritaları üretilmektedir (Heuvelink, 2006).

Toprak verimliliğini etkileyen tüm değişkenlik süreçlerinin takip edilmesi, belirlenmesi, yorumlanması ve etkili bir yönetim biçimi geliştirebilmek açısından oldukça önemlidir. Samsun ili sınırları içerisinde yer alan İdrisli, Muhsinli, Beyköy, Kaya, Seyitali ve Çayırlı mahallelerine ait toplam 1523 parselden oluşan ve 3778.3 dekar alanda yapılan bu çalışmada, Coğrafi Bilgi Sistemleri yardımı ile toprak verimlilik özelliklerinin belirlenmesi, haritalanması ve içerdikleri karakteristik durumlara göre yönetim biçimlerinin ortaya konulması amaçlanmıştır.

\section{Materyal ve Yöntem}

\section{Araştırma alanı genel özellikleri}

Çalışma alanı Samsun ili Kavak ilçesi sınırları içerisinde İdrisli, Muhsinli, Çayırlı, Beyköy, Seyitali ve Kaya mahallelerinde, toplam 1523 parsel üzerinde ve 397.28 ha alanda gerçekleştirilmiştir. Çalışma alanı, 748000-753000 D ve 4553000$4556500 \mathrm{~K}$ (Zone 36, WGS84, UTM, m) koordinatları arasında ve deniz seviyesinden ise 600-825 m yükseklikte yer almaktadır (Şekil 1).
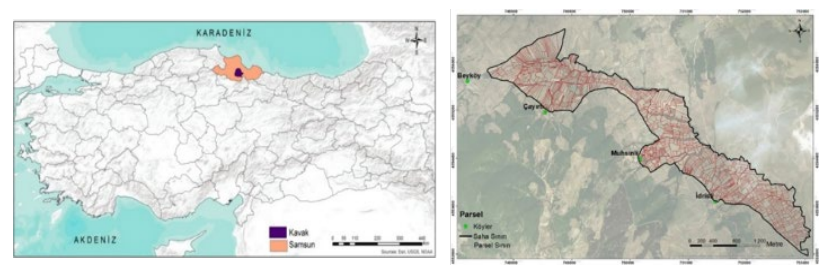

Şekil 1. Şekil 1. Çalışma sahası lokasyon ve parsel haritası

Çalışma sahasına ait sayısal yükseklik modeli yardımıyla eğim ve bakı haritası Şekil 2 de verilmiștir. Çalışma sahasının büyük bir çoğunluğu (\%76.1) hafif ve orta dik eğime sahip olup, yalnız \%2 civarındaki alanlar ise düz ve düze yakın eğimlidir. Toplam alanın \%23.6'sı ise dik ve çok dik sahaları oluşturmaktadır. Ayrıca, alanda en fazla hakim olan bakı ise kuzeydoğu ve doğu yöneyleri olarak belirlenmişken, batı ve güneybatı yöneyleri ise en az alanı kapladığı yöneyler olduğu belirlenmiştir.

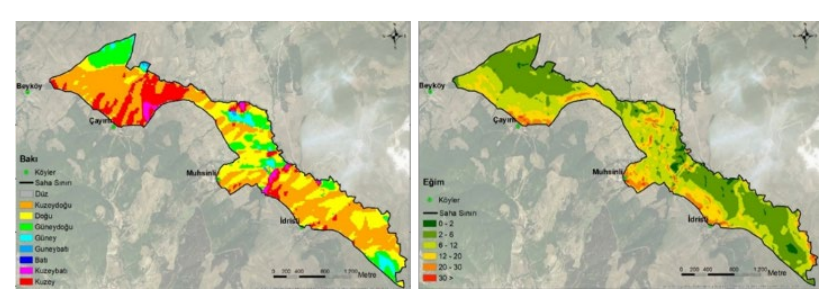

Şekil 2. Çalışma alanına ait eğim ve bakı haritaları

Araştırma alanı (Thornthwaite, 1948) iklim sınıflaması dikkate alındığında C2,B'1,s, b'4 sembolleri ile ifade edilen; yarı nemli, 1 . dereceden mezotermal, yazın orta derecede su noksanı, deniz etkisine yakın bir iklime sahiptir. Uzun yıllar (19892016) ylllk ortalama uzun yıllar meteorolojik ölçümlere göre, yıllık ortalama sıcaklığı $10.3{ }^{\circ} \mathrm{C}$ ve yıllık ortalama yağış miktarıda 512.5 mm'dir. Newhall model sonucuna göre toprak sıcaklık rejimi Mesic nem sinıflaması ise Typic xeric olarak belirlenmiștir (Turan vd, 2018). Çalıșma alanı içerisinde yalnızca buğday tarımı yapılmaktadır. Çalışma alanına ait detaylı toprak etüd ve haritalama çalışması ise Aydın (2018) taradından gerçekleștirilmiştir (Şekil 3). Topraklar \%67.5 ile Entisoller en fazla alan kaplarken, bunu sirasiyla $\% 21.8$ ile Inceptisoller ve \%10.6 ile Vertisoller izlemektedir. Ayrıca, Çayırlı serisi \%24.08 ile en fazla büyüklüğe sahip toprak serisi iken, İdrisli serisi ise \%8.17'lik oran ile en az alana sahip seri olarak belirlemiştir. 


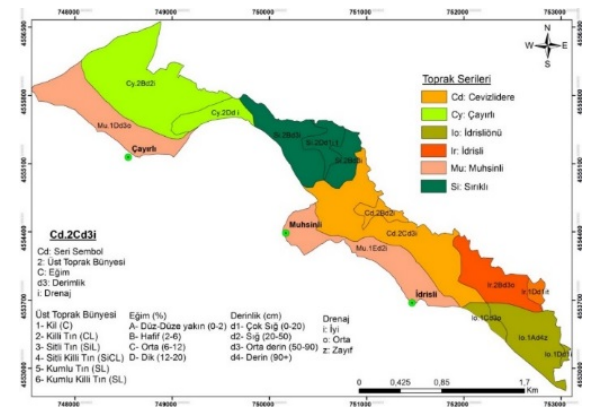

Şekil 3. Çalışma alanı temel toprak haritası

\section{Örnekleme planı ve toprak analiz yöntemleri}

Yaklaşık 397.3 ha'lık alan kaplayan çalışma alanı içerisinde $200 \mathrm{~m}$ x $200 \mathrm{~m}$ şeklinde oluşturulan grit sisteminden yüzeyden $(0-20 \mathrm{~cm}) 119$ adet ve yüzey altı $(20-40 \mathrm{~cm})$ derinlikten 115 adet toplam 233 adet toprak örneklemesi yapılmıştır. Toprak örneklemesine ait desen Şekil 4' de verilmiștir.

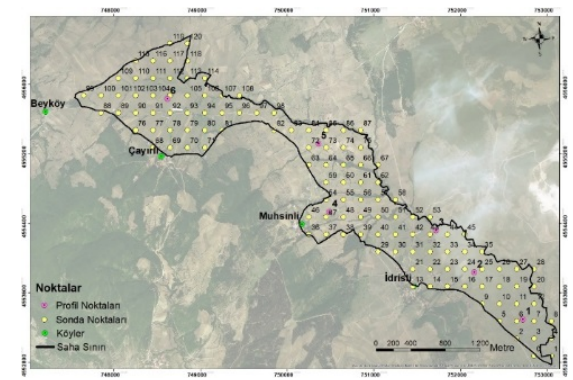

Şekil 4. Toprak örnekleme deseni

Alınan toprak örnekleri fiziksel, kimyasal ve verimlilik analizler için laboratuvara getirilmiştir. Laboratuvara getirilen bu örnekler hava kurusu hale getirildikten sonra sap, kök vb. maddelerden ayıklanıp $2 \mathrm{~mm}$ elekten geçirilerek analize hazır hale getirilmiștir. Bünye analizi (Bouyoucos, 1962), hacim ağırlığı (Blake ve Hartge, 1986), hidrolik iletkenlik (Klute ve Dirksen, 1986), pH 1:2.5'lik toprak-su karışımında (Ülgen ve Yurtsever, 1995), EC (1:2.5’lik toprak-su karışımında (Ülgen ve Yurtsever, 1995), organik madde (Jackson, 1958), katyon değişim kapasitesi (Rhoades, 1982), değişebilir katyonlar (Loue, 1968), Scheibler kalsimetresi ile volümetrik kireç (Nelson ve Sommers, 1982), Olsen yöntemine göre alınabilir fosfor (P) (Olsen, 1954), $1 \mathrm{~N}$ amonyum asetat $\left(\mathrm{NH}_{4} \mathrm{OAc}\right)$ ekstraksiyon yöntemiyle alınabilir potasyum (K) (Anonymous, 1992) ve azot (N) kapsamı analizi ise Mikro Kjeldahl metodu ile (Bremner ve Mulvaney, 1982) belirlenmiştir. Toprakların demir (Fe), bakır (Cu), çinko $(\mathrm{Zn})$ ve mangan (Mn) içerikleri ise; DTPA ile ekstraksiyon sonrasında elde edilen çözeltinin atomik adsorbsiyon spektrofotometresinde okunmasıyla (Anonymous, 1990) saptanmıştır. Toprak özelliklerinin aralı sınıflarının değerlendirilmesinde, (Lindsay ve Norvel, 1978) ile (Ülgen ve Yurtsever, 1995) tarafından bildirilen sınır değerler kullanılmıştır.

\section{Tanımlayıcı istatistik ve enterplasyon modeller}

Toprak analizlerinden elde edilen noktasal verilerin alansal dağılımını belirlemek için enterpolasyon modelleri kullanılması suretiyle en uygun model belirlenerek çalıșma alanı topraklarının bazı fizikokimyasal özellikleri ve besin element içeriklerinin dağılım haritaları üretilmiştir. Çalışma alnında koordinatları belirlenmiş örnekleme noktalarından alınan toprak örneklerinin analiz sonuçları ve çalışma alanının coğrafik verileri enterpolasyon metotları kullanılarak ArcGIS 10.2.2 konumsal dağılım haritaları hazırlanmıştır.

Bu çalışma kapsamında deterministik yöntemlerden Radyal Tabanlı Fonksiyon (RBF), Ters Mesafe Ağırlıklı Enterpolasyon (IDW) yöntemi, stokastik yöntemlerden Ordinary Kriging (OK), Basit Kriging (SK), Universal Kriging (UK) metotları karşılaştırılmıştır. Çalışmada IDW metodunda birinci, ikinci ve üçüncü kuvvet (IDW-2, IDW-2, IDW3), RBF metodunda Düzeltilmiş Spline (Completely Regularized Spline (CRS), İnce Plaka Spline (Thin Plate Spline TPS), ve Spline With Tension (ST) modelleri, kriging metotlarında ise Küresel (Spherical), Üssel (Exponential) ve Gaussian modelleri kullanılmıştır. Yöntemlerin karşılaştırılması ve değerlendirilmesinde genel olarak en yaygın kullanılan yöntemler; Ortalama Hata Kareleri Toplamının Karekökü (RMSE) ve ortalama mutlak hata (MAE), tahmin edilen ve gözlenen değerler arasındaki korelasyon değerlerinin kullanıldığı yöntemlerdir. Bu çalışmada en uygun yöntemlerin seçilebilmesi için yöntemlerin karşılaştırmalarında Ortalama Hata Kareleri Toplamının Karekökü (RMSE) yöntemi kullanılmıştır. Model belirlemede ise en düşük RMSE değerini veren yöntem en uygun yöntem olarak değerlendirilmiştir. RMSE değerlerinin hesaplanmasında aşağıdaki eşitlikler kullanılmıştır (Ding ve ark., 2011)

$R M S E=\sqrt{\frac{\sum\left(Z_{i *}-Z_{i}\right)^{2}}{n}}$

Eşitlikte; $Z_{i}$ : tahmin edilen değer, $Z_{i^{*}}$ ölçülen değer be $n$ örnek sayısını ifade etmektedir. 
Çalışma alanına ait elde edilen toprak analiz sonuçlarına ait tanımlayıcı istatistikler SPSS 12.0 paket programında yapılmış, uygunluk sınıfların konumsal dağılım alanlarının belirlenmesinde ise ArcGIS 10.2v programları kullanılmıștır.

\section{Bulgular ve Taratışıma}

Toprakları temel tanımlayıcı istatistik özellikleri

Çalışma alanından 0-20 cm ve $20-40$ derinliklerden alınan toprak örneklerine ait en küçük, en büyük, standart sapma, varyasyon katsayısı, ortalama çarpıklık-basıklık gibi tanımlayıcı istatistiklerin analiz sonuçları Çizelge 1'de verilmiştir. Bir veri setinde verilerin simetrik dağlması normal bir dağılım göstermesi demektir. Normal dağılımda ise simetrikliğin bozulma derecesine çarpıklık (skewness) denilmektedir. Dağılış sağa uzun kuyruklu ise sağa (pozitif) çarpık, sola uzun kuyruklu ise sola (negatif) çarpık olarak adlandırılır. Normal dağılım eğrisinin sivrilik veya yuvarlaklık derecesine basıklık (kurtosis) denir (Yıldız ve ark., 1999). Çizelge 1 incelendiğinde çarpıklık katsayıları yüzey topraklarında $\mathrm{Ca}, \mathrm{P}, \mathrm{Cu}, \mathrm{pH}$ ve $\mathrm{OM}$ normal dağılım sergilerken diğer özellikler ise normal dağılımdan uzaktır. Normal dağılımdan uzak $\mathrm{EC}$ ve $\mathrm{CaCO}_{3}$ negatif (sola) çarpıklığa sahipken diğer normal dağılmayan özellikler ise pozitif (sağa) çarpıktır (Wilding, 1985), toprak özelliklerindeki değişimlerin açıklanmasında önemli bir gösterge olarak kabul edilen değişkenlik katsayısını, aldığı değerlere göre düşük (<\%15), orta $(\%$ 15-35) ve yüksek (>\%35) olarak sınıflandırmaktadır (Mallants ve ark., 1996; Sağlam, 2013). Buna göre çalışma alanında $\mathrm{N}$ ve $\mathrm{Cu}$ düşük değişkenlik göstermekte, $\mathrm{CaCO}_{3}$ orta değişkenlikte diğer toprak özellikleri ise yüksek değişkenliktedir. Yüzey altı örnekleri incelendiğinde ise $\mathrm{Fe}, \mathrm{Cu}, \mathrm{pH}$ ve EC normal dağılım sergilerken, Ca sola çarpık (negatif) özellik, $\mathrm{CaCO}_{3}$ ve $\mathrm{OM}$ sağa çarpık pozitif özellik sergilemektedir. OM, pH, EC, Cu ve $\mathrm{Zn}$ düşük değişkenliğe sahipken diğerleri ise yüksek değișkenliğe sahiptir.

\section{Enterpolasyon modeller ve dağılım haritaları}

Kabaca enterpolasyon; bilinmeyen bir fonksiyonun, bilinen değișken değer setlerini kullanarak bilinen bir fonksiyon elde etme yöntemi olarak tanımlanmaktadır (Anonymous, 2002). Enterpole edilecek veri seti içerisinde bulunan değerlerin nasıl bir dağılım yaptığını belirleyebilmek için deterministik ve stokastik yöntemler kullanılabilmektedir. Deterministik yöntemler arasında en fazla IDW ve RBF yöntemleri, stokastik yöntemlerden ise Ordinary, Universal ve Simple yöntemleri kullanılmaktadır. Toprak analiz sonuçlarına göre elde edilmiş olan noktasal verilerin çalışma alanında nasıl bir dağılım yaptığını belirleyebilmek için farklı karşılaştırma yöntemleri kullanılabilir (Arslan, 2012; Taşan ve Demir, 2017). Bunlar, veri setinin en düşük Hata Kareleri Toplamının Karekökü (RMSE) ya da Ortalama Mutlak Hata (MAE) yöntemleridir. ArcGIS 10.2.2 programı içerisinde "Geosatistical Extension" birimi, üretilen haritalarda tahminin ortalama hatası (ME) ve tahminin standardize ortalama hatalar karekökü kriterlerini kullanmaktadır (RMSE) (Çelik ve Dengiz, 2018). Haritalama işleminde kullanılacak yöntemin belirlenmesi için hesaplanan RMSE değerleri yüzey ve yüzey altı topraklar için Çizelge 2 ve Çizelge 3'de verilmiştir. Her bir verimlilik parametresi için bu değerlerden en düşük olan yöntem uygulanmak sureti ile dağılım haritalama işlemi gerçekleştirilmiştir.

Yüzey toprak $(0-20 \mathrm{~cm})$ örneklerinde $\mathrm{Mg}$ ve $\mathrm{N}$ parametrelerine ait dağılımı belirlemek için kriging modeli içerisinde yer alan basit krigingden üstel model en uygun olarak belirlenirken, organik madde ve kum parametrelerinin dağılımı için yine basit krigingden Gaussian modeli en uygun model olarak belirlenmiştir. $\mathrm{Na}, \mathrm{K}, \mathrm{P}, \mathrm{CaCO}_{3}$ ve silt parametrelerinin dağılımının belirlenmesi için ise aynı yöntemin küresel modeli en uygun model olarak belirlenmiștir. Ca ve Mn parametrelerine ait dağılımların belirlenmesi için ise kriging modeli içerisinde yer alan doğal kriging yöntemi içerisinden Ca parametresi için Gaussian modeli, Mn parametresi için ise küresel model en uygun model olarak belirlenmiștir. $\mathrm{Zn}$ ve $\mathrm{Cu}$ parametrelerine ait dağılımların belirlenmesi için RBF model içerisinden CRS, Fe parametresine ait dağllımın belirlenmesi için ise kriging modeli içerisinde yer alan evrensel yöntemden küresel model en uygun olan model olarak belirlenmiştir.

Yüzey altı $(20-40 \mathrm{~cm})$ topraklarına ait parametrelerin dağılımlarının belirlenmesine yönelik en uygun modeller incelendiğinde, kil parametresine ait dağılımların belirlenmesi için kriging modeli içerisinde yer alan doğal krigingden küresel model uygunken, Mn parametresi dağılımı için IDW'nin birinci kuvveti uygun olarak belirlenmiștir. $\mathrm{Zn}, \mathrm{Na}, \mathrm{OM}, \mathrm{Ca}$ ve kum parametrelerine ait dağılımların belirlenmesi için kriging modeli içerisinde yer alan basit krigingden Gaussian model en uygun olarak belirlenirken, $\mathrm{Cu}$, 
Mg ve silt parametrelerinin dağılımlarının belirlenmesi için aynı yöntemin üstel modeli uygun olarak belirlenmiştir. $\mathrm{K}, \mathrm{P}, \mathrm{Fe}, \mathrm{CaCO}_{3}$ ve $\mathrm{N}$ parametre değerlerinin dağılımlarının belirlenmesi için ise yine aynı yöntemin küresel modeli uygun olarak belirlenmiştir. Çalışma alanına ait yüzey ve yüzey altı toprak örneklerinin bazı fiziksel ve kimyasal analiz sonuçları Çizelge 3' de, kil, silt ve kum dağılım haritaları ise Şekil 5'de verilmiștir. Vertisol topraklardan oluşmuş İdrisliönü serisi, İdrisli serisi, Cevizlidere serisine ait $\mathrm{Cd} .2 \mathrm{Cd} 3 \mathrm{i}$ haritalama biriminin olduğu alanlar ile Sırıklı serisinin doğu kesimlerinde dağılım gösteren topraklar \%40 ile \%60 arasında kil içeriğine sahiptir. Buna karşın, en az kil dağılımı gösteren topraklar ise alanın kuzeyinde bulunan Çayırlı serine ait bölgelerde tespit edilmiş olup, bu toprakların kil içeriği \%15'inde altındadır. Çalışma alanına ait yüzey altı toprak örneklerine ait kil dağılım durumları ise yine özellikle vertisol topraklardan oluşmuş İdrisliönü serisi, İdrisli serisi ve Cevizli dere serisine ait Cd.2Cd3i haritalama biriminin olduğu kesim \%50’lere ulaşan kil içeriğine belirlenirken, yüzeyde olduğu gibi Sırıklı serisinin doğu kesimi ve Çayırlı serisine ait Cy.2Bd2i haritalama biriminin olduğu bölgede yine \%50’lere varan ağır killi topraklar olarak belirlenmiştir. Benzer şekilde, en az kil içeriğine sahip yüzey altı topraklar, yüzey topraklarında olduğu gibi alanın kuzeyinde bulunan Çayırlı serine ait bölgelerde tespit edilmiş olup, kil içeriği \%20 ve altında oldukları saptanmıştır.

Çalışma alanı topraklarının silt fraksiyonunun bulunduğu tekstür sinıfları oldukça düşük oranlardadır ve toprakların silt içerikleri \%7.48\%65.28 arasında değişmektedir. Çalışma alanın büyük bir bölümünde silt dağılımı alansal olarak \%25 civarlarında olmakla beraber, bünye sınıfı içerisinde düşük değerler almaktadır.

Çizelge 1. Toprakların verimlilik özelliklerinin tanımlayıcı istatistikleri

\begin{tabular}{|c|c|c|c|c|c|c|c|c|c|}
\hline $\begin{array}{c}\text { Tanımlayıcı } \\
\text { İstatistik }\end{array}$ & Derinlik & Ort. & S.S & $\mathrm{DK}^{*}$ & Varyans & EDD & EYD & Çar.** & Bas. \\
\hline Kum & $0-20$ & 36.96 & 8.08 & 41.27 & 65.42 & 21.04 & 62.31 & 0.55 & 0.47 \\
\hline$\%$ & $20-40$ & 35.01 & 8.59 & 42.35 & 73.92 & 16.2 & 58.60 & 0.64 & 0.37 \\
\hline Silt & $0-20$ & 24.98 & 6.25 & 57.87 & 39.08 & 7.41 & 65.28 & 1.98 & 14.33 \\
\hline$\%$ & $20-40$ & 24.58 & 4.54 & 27.49 & 20.65 & 7.41 & 34.90 & -0.67 & 2.06 \\
\hline Kil & $0-20$ & 38.05 & 8.62 & 56.39 & 74.33 & 2.45 & 58.84 & -0.72 & 1.66 \\
\hline$\%$ & $20-40$ & 40.40 & 8.47 & 42.79 & 71.87 & 20.6 & 63.39 & -0.31 & -0.11 \\
\hline $\mathrm{pH}$ & $0-20$ & 7.03 & 0.49 & 2.25 & 0.24 & 5.80 & 8.05 & -0.32 & -0.99 \\
\hline$(1: 2.5)$ & $20-40$ & 7.29 & 0.41 & 1.7 & 0.16 & 6.33 & 8.03 & -0.4 & -0.87 \\
\hline EC & $0-20$ & 0.02 & 0.0 & 0.06 & 0.0 & 0.01 & 0.07 & 2.02 & 11.87 \\
\hline$\left(\mathrm{dS} . \mathrm{m}^{-1}\right)$ & $20-40$ & 0.02 & 0.0 & 0.02 & 0.0 & 0.01 & 0.03 & -0.2 & -1.02 \\
\hline $\mathrm{CaCO}_{3}$ & $0-20$ & 3.99 & 3.79 & 20.95 & 14.37 & 0.32 & 21.27 & 2.08 & 5.28 \\
\hline$(\%)$ & $20-40$ & 4.78 & 6.43 & 42.45 & 41.35 & 0.32 & 42.77 & 3.29 & 13.82 \\
\hline $\mathrm{OM}$ & $0-20$ & 3.04 & 1.08 & 5.3 & 1.18 & 0.63 & 5.93 & 0.4 & 0.15 \\
\hline$(\%)$ & $20-40$ & 2.07 & 0.98 & 5.71 & 0.97 & 0.14 & 5.85 & 1.27 & 2.23 \\
\hline $\mathrm{N}$ & $0-20$ & 0.26 & 0.21 & 2.32 & 0.04 & 0.11 & 2.43 & 9.14 & 93.22 \\
\hline$\left(\mathrm{mg} \mathrm{kg}^{-1}\right)$ & $20-40$ & 1.89 & 9.23 & 57.07 & 85.31 & 0.07 & 57.14 & 5.31 & 26.92 \\
\hline $\mathrm{Ca}$ & $0-20$ & 4922.1 & 1285.1 & 6323.2 & 1651565.7 & 2161.5 & 8484.7 & 0.27 & -0.04 \\
\hline$\left(\mathrm{mg} \mathrm{kg}^{-1}\right)$ & $20-40$ & 5098.5 & 1635.8 & 9298.8 & 2675717.3 & 7.41 & 9306.23 & -0.55 & 1.79 \\
\hline $\mathrm{Mg}$ & $0-20$ & 709.15 & 588.37 & 2850.5 & 346179.35 & 26.1 & 2876.59 & 1.74 & 3.03 \\
\hline$\left(\mathrm{mgkg}^{-1}\right)$ & $20-40$ & 813.05 & 673.74 & 4059.4 & 453928.42 & 20.6 & 4080 & 1.58 & 3.93 \\
\hline $\mathrm{Na}$ & $0-20$ & 52.84 & 25.96 & 142.54 & 674.13 & 15.47 & 158.01 & 1.72 & 3.72 \\
\hline$\left(\mathrm{mg} \mathrm{kg}^{-1}\right)$ & $20-40$ & 65.11 & 37.5 & 329.67 & 1406.5 & 1.2 & 330.87 & 3.13 & 20.41 \\
\hline $\mathrm{K}$ & $0-20$ & 215.97 & 134.34 & 697.7 & 18048.1 & 49.92 & 747.62 & 1.77 & 3.72 \\
\hline$\left(\mathrm{mg} \mathrm{kg}^{-1}\right)$ & $20-40$ & 153.46 & 86.5 & 513.32 & 7482.65 & 0.01 & 513.33 & 1.63 & 4.29 \\
\hline $\mathrm{P}$ & $0-20$ & 21.15 & 14.59 & 65.28 & 213.07 & 0.77 & 66.05 & 1 & 0.63 \\
\hline$\left(\mathrm{mg} \mathrm{kg}^{-1}\right)$ & $20-40$ & 14.46 & 13.92 & 72.2 & 193.97 & 0.38 & 72.58 & 2.13 & 5.35 \\
\hline $\mathrm{Cu}$ & $0-20$ & 2.888 & 1.12 & 5.05 & 1.26 & 0.58 & 5.63 & 0.14 & -0.44 \\
\hline$\left(\mathrm{mg} \mathrm{kg}^{-1}\right)$ & $20-40$ & 37.75 & 19.59 & 83.53 & 384.11 & 0 & 83.53 & 0.16 & -0.7 \\
\hline $\mathrm{Zn}$ & $0-20$ & 5.143 & 12.53 & 90.4 & 157.19 & 0.57 & 90.97 & 5.1 & 28.91 \\
\hline$\left(\mathrm{mg} \mathrm{kg}^{-1}\right)$ & $20-40$ & 51.15 & 43.07 & 184.71 & 1855.39 & 4.03 & 188.74 & 1.48 & 1.58 \\
\hline $\mathrm{Fe}$ & $0-20$ & 48.03 & 30.51 & 115.57 & 931.012 & 6.32 & 121.89 & 0.62 & -0.59 \\
\hline$\left(\mathrm{mg} \mathrm{kg}^{-1}\right)$ & $20-40$ & 2.66 & 0.97 & 4.84 & 0.94 & 0.58 & 5.42 & 0.2 & -0.08 \\
\hline $\mathrm{Mn}$ & $0-20$ & 56.37 & 38.59 & 173.86 & 1489.77 & 7.54 & 181.4 & 1.13 & 0.7 \\
\hline$\left(\mathrm{mg} \mathrm{kg}^{-1}\right)$ & $20-40$ & 1.51 & 1.26 & 7.75 & 1.59 & 0.57 & 8.32 & 3.06 & 10.93 \\
\hline
\end{tabular}

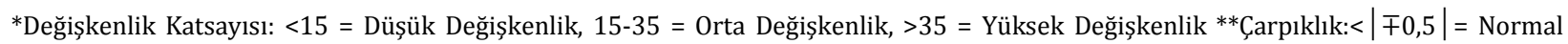
Dağılım, 0,5-1,0 = Veri setine karakter dönüşümü uygulanır. ÇK> 1,0 $\rightarrow$ Logaritma dönüşümü uygulanır. Ort: ortalama, S.S: Standart Sapma, EDD: En Düşük Değer, EYD: En Yüksek Değer, Çar.: Çarpıklık, Bas.: Basıklık, Değişkenlik katsayısı 
Çizelge 2. Yüzey ve yüzey altı toprak örneklerinin fiziko-kimyasal ve verimlilik parametrelerine ait enterpolasyon modellerin RMSE değerleri

\begin{tabular}{|c|c|c|c|c|c|c|c|c|c|c|c|c|c|c|c|}
\hline \multirow{3}{*}{$\begin{array}{c}0-20 \\
\mathrm{~cm}\end{array}$} & \multirow{2}{*}{\multicolumn{3}{|c|}{ IDW }} & \multirow{2}{*}{\multicolumn{3}{|c|}{ RBF }} & \multicolumn{9}{|c|}{ KIRIGING } \\
\hline & & & & & & & \multicolumn{3}{|c|}{ OR } & \multicolumn{3}{|c|}{ SM } & \multicolumn{3}{|c|}{ UN } \\
\hline & 1 & 2 & 3 & TPS & CRS & SWT & G & Ü & $\mathrm{K}$ & G & Ü & $\mathrm{K}$ & G & Ü & $\mathrm{K}$ \\
\hline Kil & 7.904 & 7.803 & 7.803 & 8.509 & 7.811 & 7.795 & 7.856 & 7.850 & 7.908 & 7.755 & 7.739 & 7.788 & 7.856 & 7.850 & 7.908 \\
\hline Kum & 8.479 & 8.496 & 8.566 & 10.426 & 8.667 & 8.536 & 8.593 & 8.591 & 8.593 & 8.117 & 8.117 & 8.118 & 8.593 & 8.591 & 8.593 \\
\hline Silt & 6.350 & 6.313 & 6.337 & 7.108 & 6.296 & 6.246 & 6.270 & 6.264 & 6.282 & 6.093 & 6.093 & 6.089 & 6.270 & 6.264 & 6.282 \\
\hline $\mathrm{N}$ & 0.218 & 0.22 & 0.223 & 0.265 & 0.225 & 0.222 & 0.214 & 0.214 & 0.214 & 0.21 & 0.209 & 0.209 & 0.214 & 0.214 & 0.214 \\
\hline $\mathrm{Mg}$ & 613.895 & 623.186 & 635.882 & $\begin{array}{c}788.65 \\
2\end{array}$ & $\begin{array}{c}648.11 \\
8\end{array}$ & 635.274 & 607.853 & 610.091 & 609.109 & 586.749 & $\begin{array}{c}586.65 \\
7\end{array}$ & $\begin{array}{c}586.91 \\
9\end{array}$ & 607.853 & 610.091 & 609.109 \\
\hline $\mathrm{CaCO}_{3}$ & 3.828 & 3.821 & 3.848 & 4.691 & 3.868 & 3.827 & 3.813 & 3.812 & 3.859 & 3.743 & 3.749 & 3.735 & 3.813 & 3.812 & 3.859 \\
\hline $\mathrm{Ca}$ & 1226.63 & 1239.50 & 1254.47 & 1468.2 & 1272.3 & 1255.38 & 1225.17 & 1225.78 & 1226.34 & 1242.98 & 1242.3 & 1242.3 & 1225.17 & 1225.78 & 1226.34 \\
\hline P & 14.731 & 14.727 & 14.842 & 16.474 & 14.754 & 14.669 & 14.812 & 14.824 & 14.8 & 14.275 & 14.311 & 14.239 & 14.812 & 14.824 & 14.8 \\
\hline K & 128.609 & 131.159 & 134.166 & $\begin{array}{c}160.74 \\
6\end{array}$ & $\begin{array}{c}136.42 \\
3\end{array}$ & 134.052 & 128.472 & 128.57 & 128.746 & 127.485 & $\begin{array}{c}128.14 \\
6\end{array}$ & $\begin{array}{c}127.30 \\
8\end{array}$ & 128.472 & 128.57 & 128.746 \\
\hline $\mathrm{OM}$ & 1.091 & 1.11 & 1.134 & 1.378 & 1.149 & 1.129 & 1.103 & 1.103 & 1.103 & 1.072 & 1.073 & 1.073 & 1.103 & 1.103 & 1.103 \\
\hline $\mathrm{Fe}$ & 29.014 & 28.304 & 27.862 & 29.022 & 27.523 & 27.556 & 27.349 & 27.64 & 26.939 & 27.657 & 27.854 & 27.481 & 27.349 & 27.64 & 26.939 \\
\hline $\mathrm{Na}$ & 26.918 & 26.772 & 26.809 & 30.148 & 26.779 & 26.727 & 27.059 & 27.125 & 26.95 & 25.605 & 25.707 & 25.472 & 27.059 & 27.125 & 26.95 \\
\hline $\mathrm{Cu}$ & 0.974 & 0.941 & 0.919 & 0.843 & 0.835 & 0.84 & 0.953 & 0.918 & 0.939 & 0.92 & 0.883 & 0.921 & 0.953 & 0.918 & 0.939 \\
\hline $\mathrm{Mn}$ & 36.792 & 36.577 & 36.602 & 40.148 & 36.503 & 36.437 & 36.796 & 37.015 & 36.364 & 36.863 & 36.62 & 36.754 & 36.796 & 37.015 & 36.364 \\
\hline $\mathrm{Zn}$ & 11.999 & 11.738 & 11.566 & 11.633 & 11.225 & 11.289 & 12.315 & 11.737 & 11.939 & 12.542 & 12.512 & 12.602 & 12.315 & 11.737 & 11.939 \\
\hline \multicolumn{16}{|c|}{$20-40 \mathrm{~cm}$} \\
\hline Kil & 7.837 & 7.814 & 7.850 & 9.455 & 7.909 & 7.812 & 7.664 & 7.663 & 7.641 & 7.708 & 7.703 & 7.707 & 7.664 & 7.663 & 7.641 \\
\hline Kum & 8.479 & 8.496 & 8.566 & 10.426 & 8.667 & 8.536 & 8.593 & 8.591 & 8.593 & 8.117 & 8.117 & 8.118 & 8.593 & 8.591 & 8.593 \\
\hline Silt & 4.101 & 4.090 & 4.110 & 4.685 & 4.114 & 4.097 & 4.099 & 4.104 & 4.089 & 4.041 & 4.037 & 4.056 & 4.099 & 4.104 & 4.089 \\
\hline $\mathrm{N}$ & 0.058 & 0.059 & 0.06 & 0.069 & 0.06 & 0.059 & 0.059 & 0.059 & 0.059 & 0.056 & 0.056 & 0.056 & 0.059 & 0.059 & 0.059 \\
\hline Mg & 688.449 & 700.133 & 713.532 & 805.057 & 716.328 & 708.356 & 695.305 & 694.994 & 695.554 & 667.073 & 666.935 & 667.124 & 695.305 & 694.994 & 695.554 \\
\hline $\mathrm{CaCO}_{3}$ & 6.477 & 6.425 & 6.454 & 7.113 & 6.397 & 6.377 & 6.479 & 6.49 & 6.458 & 6.374 & 6.375 & 6.372 & 6.479 & 6.49 & 6.458 \\
\hline $\mathrm{Ca}$ & 1352.51 & 1362.34 & 1392.82 & 1730.64 & 1397.19 & 1376.59 & 1336.505 & 1336.32 & 1337.84 & 1322.78 & 1323.44 & 1323.22 & 1336.505 & 1336.32 & 1337.84 \\
\hline$P$ & 14.335 & 14.469 & 14.711 & 18.019 & 14.812 & 14.612 & 14.715 & 14.719 & 14.497 & 13.799 & 13.805 & 13.792 & 14.715 & 14.719 & 14.497 \\
\hline K & 72.922 & 73.918 & 75.444 & 93.898 & 76.902 & 75.385 & 73.002 & 73.573 & 73.346 & 72.019 & 72.068 & 71.954 & 73.002 & 73.573 & 73.346 \\
\hline $\mathrm{OM}$ & 1.018 & 1.047 & 1.081 & 1.328 & 1.095 & 1.068 & 1.017 & 1.019 & 1.023 & 0.987 & 0.988 & 0.989 & 1.017 & 1.019 & 1.023 \\
\hline $\mathrm{Fe}$ & 19.416 & 19.601 & 19.983 & 24.882 & 20.111 & 19.753 & 19.767 & 19.826 & 19.775 & 18.581 & 18.565 & 18.535 & 19.767 & 19.826 & 19.775 \\
\hline $\mathrm{Na}$ & 38.092 & 38.799 & 39.659 & 47.077 & 40.208 & 39.424 & 37.628 & 37.771 & 37.722 & 36.359 & 36.359 & 36.359 & 37.628 & 37.771 & 37.722 \\
\hline $\mathrm{Cu}$ & 0.92 & 0.919 & 0.926 & 1.126 & 0.923 & 0.913 & 0.921 & 0.913 & 0.916 & 0.903 & 0.899 & 0.903 & 0.921 & 0.913 & 0.916 \\
\hline $\mathrm{Mn}$ & 36.033 & 36.71 & 37.457 & 42.698 & 37.728 & 37.219 & 36.949 & 37.169 & 36.966 & 37.393 & 38.03 & 37.463 & 36.949 & 37.169 & 36.966 \\
\hline $\mathrm{Zn}$ & 1.291 & 1.31 & 1.342 & 1.635 & 1.357 & 1.329 & 1.284 & 1.287 & 1.286 & 1.254 & 1.255 & 1.254 & 1.284 & 1.287 & 1.286 \\
\hline
\end{tabular}

IDW: Inverse Distance Weighting, RBF: Radial Polynomial Interpolation, CRS: Completely Regularized Spline, TPS: Thin Plate Spline, SWT: Spline With Tension, G: Gaussian, Ü: Üstel (Exponential), K: Küresel (Spherical), OR: Doğal (ordinary), SM: Basit (Simple), UN: Universal (Everensel)

Haritadan görüleceği üzere güney doğu bölgeleri (İdrisli ve İdrisliönü serileri) ile iç kesimlere doğru (Sırıklı serisi ve Muhsinli serisinin bazı kısımları) yayılım göstermektedir. Yapılan bünye analizi sonucunda yüzey topraklarının kum miktarı \%21.04\%62.31 arasında değişmektedir. Çalışma sahasında yer alan özellikle kuzey doğu kesinlerde dağılım gösteren yüzey toprak örnekleri suların ve yerçekimi etkileri ile tașınmıș olan çakıllı alüviyal ve kolüvyal depozitler üzerinde gelişim kumlu killi tın, kumlu kil ve kumlu tın sınıflarında yer aldığı görülmektedir. Yüzey altı topraklarında kum miktarı Muhsinli serisinin tamamına yakını, Çayırlı serisinin batı kesimi hariç diğer bölgeleri, Sırıklı serisinin Muhsinli köyüne doğru uzanan hatta ki kısmında \%40 ve üzeri kum bulunmakta diğer kesimlerde ise \%30'un altında kum içeriği saptanmıştır. Çalışma alanın toprak reaksiyonu incelendiğinde, yüzey topraklarında $\mathrm{pH}$ değerleri, 5.15 ile 8.05 değerleri arasında değişmekte olup, ortalama 7.03'tür. Toprak örneklerin yaklaşı \%66'sı nötr ve \%21'i ise hafif alkalin olarak belirlenmiştir. Örneklerin çok az bir kısmı ise hafif asit reaksiyonlu olarak belirlenmiştir. Yüzey ve yüzey altı toprakların $\mathrm{pH}$ dağılım haritaları Şekil 6'da verilmiştir. Yüzey toprak örneklerinin $\mathrm{pH}$ dağılım deseni incelendiğinde özellikle Çayırlı serisine ait Cy.2Bd2i ile gösterilen harilama birimi ile Cevizlidere ve Idrisli serilerine ait $\mathrm{Cd} .2 \mathrm{Bd} 2 \mathrm{i}$ ve Ir.2Bd3o haritalama birilerinde hafif asit reaksiyonlu olduğu görülmektedir. 
Çizelge 3. Yüzey ve yüzey altı toprak örneklerinin bazı fiziksel ve kimyasal ve verimlilik parametrelerine ait dağılım oranları

\begin{tabular}{|c|c|c|c|c|c|c|}
\hline \multirow[t]{2}{*}{ Parametre } & \multirow[t]{2}{*}{ Sinif } & \multirow[t]{2}{*}{ Tanımlama } & \multicolumn{2}{|c|}{$\begin{array}{c}\text { Yüzey } \\
(0-20 \mathrm{~cm})\end{array}$} & \multicolumn{2}{|c|}{$\begin{array}{c}\text { Yüzey altı } \\
(20-40 \mathrm{~cm})\end{array}$} \\
\hline & & & Ör. Sayısı & $\%$ & Ör. Sayısı & $\%$ \\
\hline \multirow{5}{*}{$\begin{array}{c}\text { Bünye sınıfları } \\
(\%)\end{array}$} & $>\% 50$ C. SC. SiC & & 51 & 42.86 & 65 & 56.52 \\
\hline & CL. SCL. SiCL. $<\% 50$ C & & 64 & 53.78 & 47 & 40.87 \\
\hline & vfSL. L. SiL. Si & & 2 & 1.68 & 3 & 2.61 \\
\hline & SL. fSL & & 2 & 1.68 & - & - \\
\hline & S. LS & & - & - & - & - \\
\hline \multirow{4}{*}{$\begin{array}{c}\mathrm{EC} \\
\left(\mathrm{dS} \mathrm{m}^{-1}\right)\end{array}$} & $0-4$ & Tuzsuz & 119 & 100 & 115 & 100 \\
\hline & $4-8$ & Hafif tuzlu & - & - & - & - \\
\hline & $8-15$ & Orta derecede tuzlu & - & - & - & - \\
\hline & $>15$ & Çok fazla tuzlu & - & - & - & - \\
\hline \multirow{6}{*}{$\mathrm{pH}$} & $<4.5$ & Kuvvetli asit & - & - & - & - \\
\hline & $4.5-5.5$ & Orta asit & - & - & - & - \\
\hline & $5.5-6.5$ & Hafif asit & 16 & 13.45 & 2 & 1.74 \\
\hline & $6.5-7.5$ & Nötr & 80 & 67.23 & 63 & 54.78 \\
\hline & $7.5-8.5$ & Hafif alkali & 23 & 19.33 & 50 & 43.48 \\
\hline & $>8.5$ & Kuvvetli alkali & - & - & - & - \\
\hline \multirow{5}{*}{$\mathrm{CaCO}_{3}$} & $0-1$ & Az kireçli & 26 & 21.85 & 34 & 29.57 \\
\hline & $1-5$ & Kireçli & 62 & 52.10 & 50 & 43.48 \\
\hline & $5-15$ & Orta kireçli & 28 & 23.53 & 23 & 20 \\
\hline & $15-25$ & Fazla kireçli & 3 & 2.52 & 6 & 5.22 \\
\hline & $>25$ & Çok fazla kireçli & - & - & 2 & 1.74 \\
\hline \multirow{5}{*}{$\mathrm{OM}$} & $<0.5$ & Çok az & 1 & 0.84 & 1 & 0.87 \\
\hline & $0.5-1.0$ & $\mathrm{Az}$ & 19 & 15.97 & 10 & 8.70 \\
\hline & $1.0-2.0$ & Orta & 35 & 29.41 & 57 & 49.57 \\
\hline & $2.0-3.0$ & İyi & 43 & 36.13 & 30 & 26.09 \\
\hline & $>3.0$ & Yüksek & 22 & 18.49 & 17 & 14.78 \\
\hline
\end{tabular}
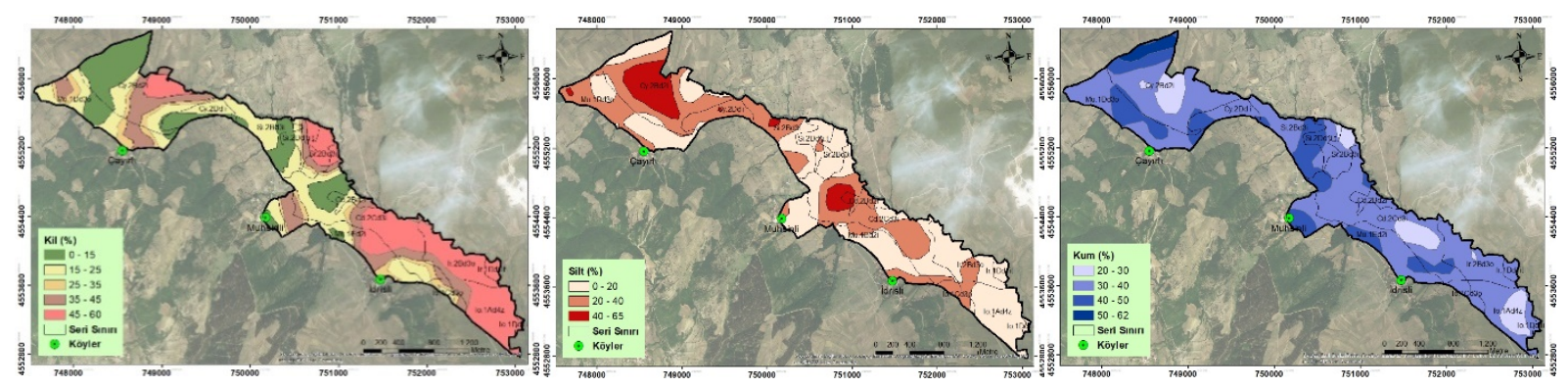

Yüzey $(0-20 \mathrm{~cm})$ kil, silt ve kum dağılım
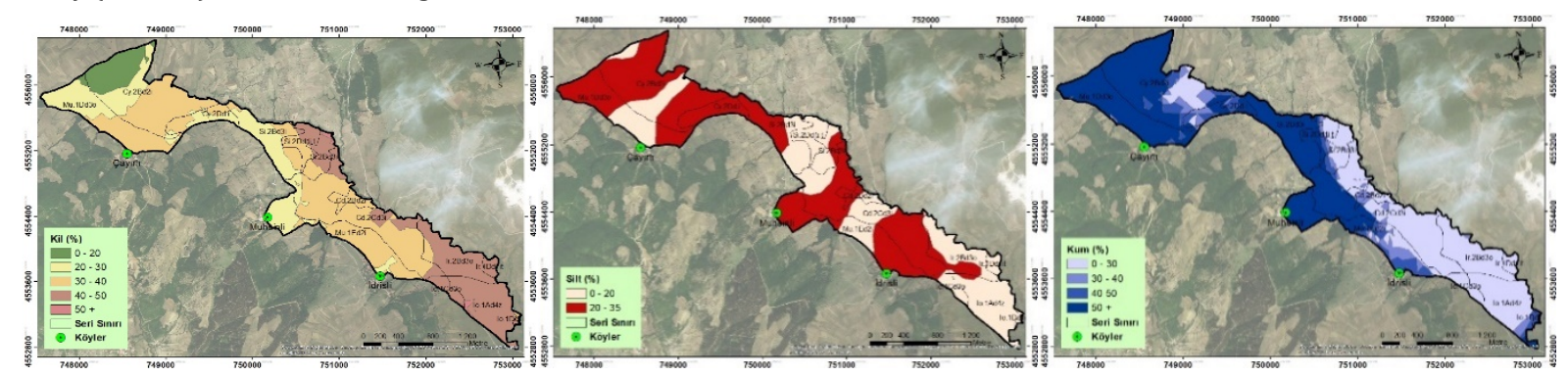

Yüzey altı (20-40 cm) kil, silt, kum dağılım

Şekil 5. Çalışma alanına ait bünye dağılım haritaları

Alanın büyük bir çoğunluğu ise toprak reaksiyonu yönünden nötr ve çok az bir kısmı ise alkalin özellik taşımaktadır. Yüzey altı topraklarının analiz sonuçları incelendiğinde $\mathrm{pH}$ değerleri 6.34 ile 8.03 arasında değişmekle beraber örneklerin \%1.74'ü hafif asit, \%54.78'i ise nötr özellik göstermektedir. Muhsinli serisine ait kuzey doğu kısmı tamamen,
Cevizlidere serisinin orta kısmı, Sırıklı serisinin Si.2Bd3i haritalama birimi hariç, genel olarak hafif alkali geri kalan kısımlar nötr olarak belirlenmiştir.

Çalışma sahasında yüzey topraklarındaki kireç dağılımı incelendiğinde, toprak örneklerinin yaklaşık $\% 26$ 'si az kireçli, \%62'si orta kireçli, \%28'ü oranında kireçli ve \%3'ü ise fazla kireçli bulunmuştur. 

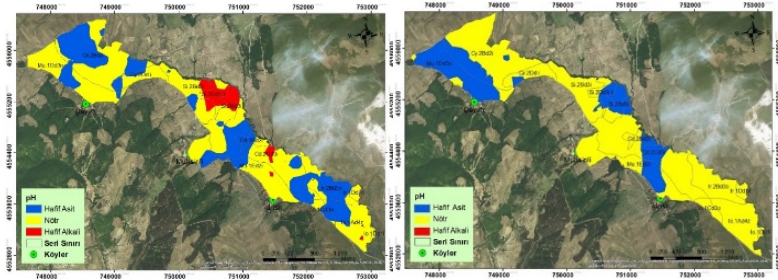

Şekil 6. Çalışma alanı yüzey (a) ve yüzey altı (b) topraklarına ait pH dağılım haritaları

Alan içerisinde nispeten düz düze yakın ve hafif eğimi olan alanlarda kireç miktarı daha düşük bulunmuştur. Toprak serisi bazında kireç dağılımı incelendiğinde, alan içerisinde yüzey topraklarında en düșük kireç içeriği ile İdrisli serisi sonrasında ise İdrisliönü serisi, Sırıklı Serisi, Cevizlidere Serisi, Muhsinli Serisi ve Çayırlı serisi olarak sıralanmaktadır. Yüzey altı topraklarda ise kireç özellikle orta ve kuzey doğuda Muhsinli serisine ait Mu.1Dd3o haritalama biriminde \%15'lere varan kireç içeriği bulunurken, diğer lanlar \%5'in altındadır. Yüzey ve yüzey altı toprakların kireç içeriklerine yönelik dağılım haritaları Şekil 7' de verilmiştir.

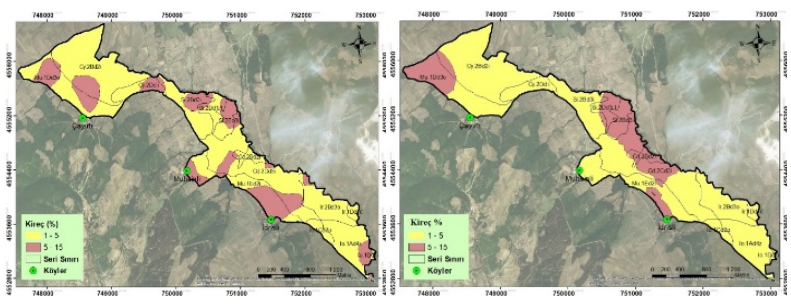

Şekil 7. Çalışma alanı yüzey (a) ve yüzey altı (b) topraklarına ait kireç dağılım haritaları

Yüzey ve yüzey altı toprakların organik madde dağılımları Șekil 8 de verilmiștir. Yüzey toprak örneklerinin organik madde kapsamı \%0.63 ile \%5.93 arasında değişmektedir ve yaklaşı \%65'i iyi ve yüksek düzeyde, geri kalan kısmının ise orta ve çok düşük arasında değişmektedir. Yüzey altı topraklarında ise ortalama olarak \%2.07 olarak belirlenmiștir. Alanın kuzey doğu kesiminde bulunan Çayırlı ve Muhsinli serilerinin çoğunda ve güneyde İdrisliönü serisinin orta ve doğu kesiminde orta seviyede bulunmuştur. Yüzey altı toprakların ise, \%9.57'inde düşük ve çok düşük seviyelerde organik madde içerikleri bulunurken, yaklaşık yarısına yakınında ise orta düzeyde organik madde bulunmaktadır. Bu dağılım da özellikle Muhsinli serisine ait Mu.1ED2i haritalama birimine ait kesimin tamamına yakın kısmında ve Sırıklı serisinin orta bölgelerinde Organik Madde miktarı iyi seviyesinde bulunmuștur.

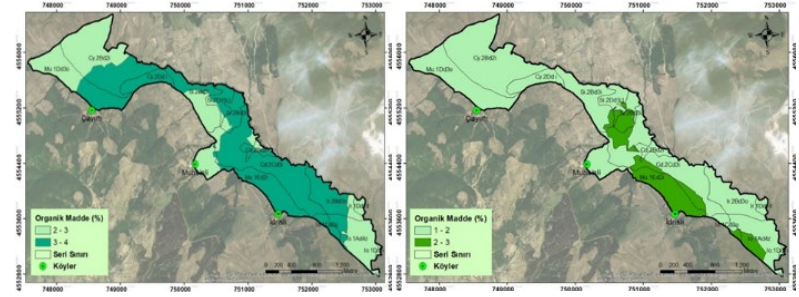

Şekil 8. Çalışma alanı yüzey (a) ve yüzey altı (b) topraklarına ait organik madde dağılım haritaları

Çalışma alanına ait yüzey ve yüzey altı toprak örneklerinin verimlilik parametrelerine ait analiz sonuçları Çizelge 4' de verilmiştir. Çalışma alanında azot kapsamı bakımından yüzey ve yüzey altı örnekleri $\% 0.17$ ile $\% 0.32$ arasında fazla olarak nitelendirilen sınıf içerisinde yer aldığından, çalışma alanında azot eksikliği saptanmamıştır. Benzer durum makro besin elementlerinden magnezyum ile mikro besin elementlerinden demir, bakır ve mangan içinde geçerlidir. Buna karşıllk çinko elementinin dağılımında ise yüzey toprak örneklerinde \%2.5 gibi çok az bir kısmında çinko az düzeyde belirlenmişken, diğer kısmında çinko içerikleri yeterli düzeyde belirlenmiştir. Fakat yüzey altı toprak örneklerinin yaklaşık \%17'lik gibi bir kısmı çinko elementi bakımından yetersiz düzeyde oldukları belirlenmiștir (Şekil 9). Toprakların makro elementlerinden olan fosfor içerikleri ise etkin madde olan $\mathrm{P}_{2} \mathrm{O}_{5}$ kg.da-1 incelendiğinde (Șekil 10), yüzey topraklarının yaklaşık \%22'de az ve çok az olduğu belirlenmiștir. Her ne kadar diğer topraklarda da yüksek ve çok yüksek düzeylerde olduğu belirlenmiş olsa da fosforun toprakların özellikle kil kapsamı ve çeşidi ile kireç miktarından önemli ölçüde etkilenmekle beraber azotun nitrat formu gibi hareketli olmayıp, toprak içerisinde immobildir. Çalışma alanında yoğun olarak tarımsal üretim olarak kuruda tahıl olarak buğday yetiştirilmektedir. Karadeniz Bölgesinde buğday bitkisi için verilmesi gereken $\mathrm{P}_{2} \mathrm{O}_{5} \mathrm{~kg} \mathrm{da}^{-1}$ miktarı Güçdemir (2006)'a göre çok az ile az olan alanlara 7$10 \mathrm{~kg} \mathrm{P} 2 \mathrm{O}_{5} \mathrm{~kg} \mathrm{da}^{-1}$, orta olan alanlara ise yaklaşık $3 \mathrm{~kg}$ $\mathrm{P}_{2} \mathrm{O}_{5} \mathrm{~kg} \mathrm{da}^{-1}$ fosfor önerilmektedir. Toprakların ağır ve kimi yerlerde kireç içeriklerinin yüksek olması nedeniyle bu oranların biraz üzerinde gübre uygulaması yapılabilir. Fosforun toprağa verilmesinde özellikle hareketsiz (immobil) element olması nedeniyle de bitki köklerinin fosfordan kolayca yararlanabilmesi için sürüm derinliğine verilmesi uygun olur. Yüzey topraklarında değişebilir potasyum içeriğinin yaklaşık \%38'i çok düşük ve düşük düzeylerde iken, geri kalan kısım yeterli ve yüksek düzeylerdedir. 
Çizelge 4. Yüzey ve yüzey altı toprak örneklerinin verimlilik parametrelerine ait dağılım oranları

\begin{tabular}{|c|c|c|c|c|c|c|}
\hline \multirow{5}{*}{$\begin{array}{l}\text { Toplam N } \\
(\%)\end{array}$} & $<0.045$ & Çok az & - & - & - & - \\
\hline & $0.045-0.090$ & $\mathrm{Az}$ & - & - & 2 & 1.74 \\
\hline & $0.090-0.170$ & Yeterli & 17 & 14.29 & 44 & 38.26 \\
\hline & $0.170-0.320$ & Fazla & 89 & 74.79 & 68 & 59.13 \\
\hline & $>0.320$ & Çok fazla & 13 & 10.92 & 1 & 0.87 \\
\hline \multirow{5}{*}{$\begin{array}{l}\text { Alınabilir Fosfor } \\
\left(\mathrm{P}_{2} \mathrm{O}_{5} \mathrm{~kg} \mathrm{da}^{-1}\right)\end{array}$} & $0-3$ & Çok az & 13 & 10.92 & 26 & 22.61 \\
\hline & $3-6$ & $\mathrm{Az}$ & 12 & 10.08 & 22 & 19.13 \\
\hline & $6-9$ & Orta & 26 & 21.85 & 33 & 28.70 \\
\hline & $9-12$ & Yüksek & 23 & 19.33 & 13 & 11.30 \\
\hline & $>12$ & Çok yüksek & 46 & 38.66 & 21 & 18.26 \\
\hline \multirow{4}{*}{$\begin{array}{l}\text { Alınabilir potasyum } \\
\qquad\left(\mathrm{K}_{2} \mathrm{O} \mathrm{kg} \mathrm{da}^{-1}\right)\end{array}$} & $0-20$ & $\mathrm{Az}$ & 5 & 4.20 & 3 & 2.61 \\
\hline & $20-30$ & Orta & 8 & 6.72 & 23 & 20.00 \\
\hline & $30-40$ & Yeterli & 22 & 18.49 & 27 & 23.48 \\
\hline & $40+$ & Yüksek & 84 & 70.59 & 88 & 76.52 \\
\hline \multirow{5}{*}{$\begin{array}{l}\text { Ekstrakte edilebilir K } \\
\qquad\left(\mathrm{mg} \mathrm{kg}^{-1}\right)\end{array}$} & $<100$ & Çok düşük & 15 & 12.61 & 27 & 23.48 \\
\hline & $100-150$ & Düşük & 30 & 25.21 & 34 & 29.57 \\
\hline & $150-200$ & Orta & 22 & 18.49 & 26 & 22.61 \\
\hline & $200-250$ & İyi & 33 & 27.73 & 18 & 15.65 \\
\hline & $250-320$ & Yüksek & 19 & 15.97 & 10 & 8.70 \\
\hline \multirow{3}{*}{$\begin{array}{l}\text { Ekstrakte edilebilir } \\
\operatorname{Mg}\left(\mathrm{mg} \mathrm{kg}^{-1}\right)\end{array}$} & $<54$ & Fakir & 3 & 2.52 & 7 & 6.09 \\
\hline & $54-115$ & Orta & 4 & 3.36 & 3 & 2.61 \\
\hline & $115>$ & İyi & 112 & 94.12 & 105 & 91.3 \\
\hline \multirow{3}{*}{$\begin{array}{l}\text { Ekstrakte edilebilir Fe } \\
\text { (mg kg-1) }\end{array}$} & $<2.5$ & Noksan (az) & - & - & - & - \\
\hline & $2.5-4.5$ & Noksanlık gösterebilir (orta) & - & - & - & - \\
\hline & $>4.5$ & İyi (yüksek) & 119 & 100 & 114 & 100 \\
\hline \multirow{2}{*}{$\begin{array}{c}\text { Ekstrakte edilebilir } \mathrm{Cu} \\
\left(\mathrm{mg} \mathrm{kg}^{-1}\right)\end{array}$} & $<0.2$ & Yetersiz & - & - & - & - \\
\hline & $>0.2$ & Yeterli & 119 & 100 & 114 & 100 \\
\hline \multirow{5}{*}{$\begin{array}{l}\text { Ekstrakte edilebilir Zn } \\
\text { (mg kg-1) }\end{array}$} & $<0.2$ & Çok az & - & - & - & - \\
\hline & $0.2-0.7$ & $\mathrm{Az}$ & 3 & 2.52 & 19 & 16.67 \\
\hline & $0.7-2.4$ & Yeter & 74 & 62.18 & 82 & 71.93 \\
\hline & $2.4-8.0$ & Fazla & 31 & 26.05 & 12 & 10.53 \\
\hline & $>8.0$ & Çok fazla & 11 & 9.24 & 1 & 0.88 \\
\hline \multirow{5}{*}{$\begin{array}{l}\text { Ekstrakte edilebilir Mn } \\
\qquad\left(\mathrm{mg} \mathrm{kg}^{-1}\right)\end{array}$} & $<4$ & Çok az & - & - & - & - \\
\hline & $4-14$ & $\mathrm{Az}$ & 3 & 2.52 & 12 & 10.53 \\
\hline & $14-50$ & Yeter & 66 & 55.46 & 66 & 57.89 \\
\hline & $50-170$ & Fazla & 49 & 41.18 & 32 & 28.07 \\
\hline & $>170$ & Çok fazla & 1 & 0.84 & 4 & 3.51 \\
\hline
\end{tabular}

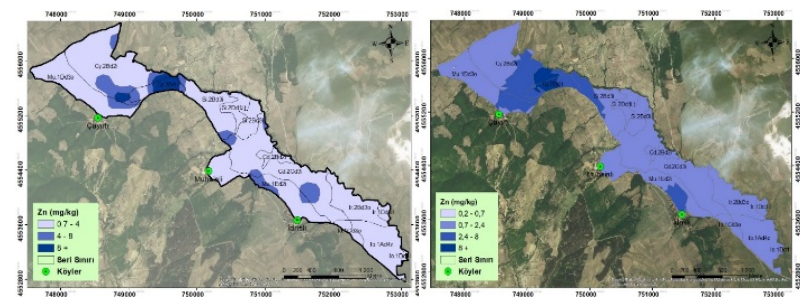

Şekil 9. Çalışma alanı yüzey (a) ve yüzey altı (b) topraklarına ait çinko dağılım haritaları

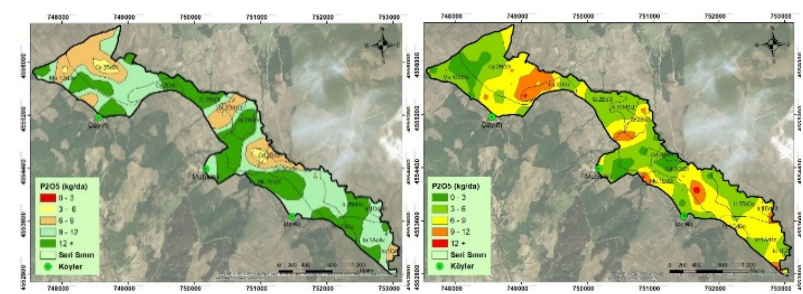

Șekil 10. Çalıșma alanı yüzey (a) ve yüzey altı (b) topraklarına ait $\mathrm{P}_{2} \mathrm{O}_{5}$ dağılım haritaları

Yüzey altı toprak örneklerinin ise yaklaşık yarısı potasyumca düşük ve çok düşük iken, toprak örneklerin yaklaşık \%24'ü iyi ve yüksek seviyede.
Potasyumun etkin maddesi olan $\mathrm{K}_{2} \mathrm{O}$ yönünden yüze ve yüzey altı dağılım haritaları Şekil 11' de verilmiştir. Karadeniz Bölgesinde buğday bitkisi için verilmesi gereken $\mathrm{K}_{2} \mathrm{O}$ kg.da-1 miktarı Güçdemir (2006)'a göre, az $12-15 \mathrm{~kg}$ ve orta düzeyde potasyum içeren topraklara 6 ile $9 \mathrm{~kg}$ arasında $\mathrm{K}_{2} \mathrm{O}$ kg.da-1 verilmesi önerilir. Ağır killi topraklarda potasyum fiksasyonu nedeniyle bitkilerin.

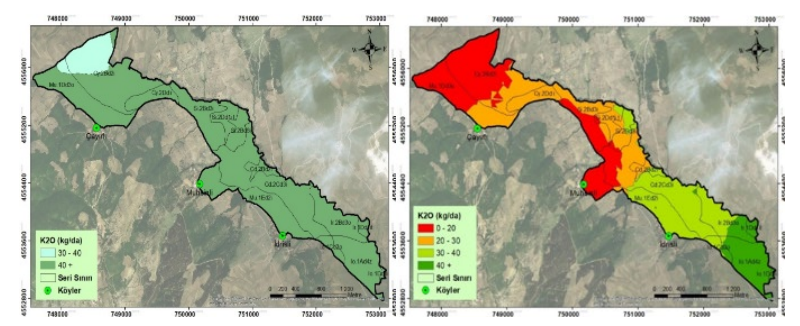

Şekil 11. Çalışma alanı yüzey (a) ve yüzey altı (b) topraklarına ait K2O dağılım haritaları

\section{Sonuç}

Sürdürülebilir tarımsal üretim ancak tarımsal girdilerin etkin ve verimli bir şekilde kullanılması ile mümkün olabilmektedir. Bu tarımsal girdilerin en 
önemlisi olan toprak, her bir üretim dönemi aralığında yani ekimden başlayıp hasada kadar süren zaman zarfında bozulmaya uğramaktadır. En iyi toprak-bitki ve arazi yönetimlerinin seçimiyle tarımda sürdürülebilirliğin sağlanması ile birlikte toprakların birçok özelliğinin iyileştirilmesine olanak vermek mümkündür. $\mathrm{Bu}$ nedenle tarım arazilerinin sürdürülebilir kullanımlarını sağlayacak planlama stratejilerinin geliştirilmesi ve çevre ile ilgili konulardaki modellemelerin yapılabilmesi için toprak, fizyografya, iklim, bitki örtüsü ve arazi kullanımı gibi temel bilgilerin yer alacağı detaylı toprak etüt ve haritalama çalışmalarına ve süreç içerisinde izleme, değerlendirme ve güncellemeye imkan veren bir toprak veri tabanına ihtiyaç duyulmaktadır.

Çalıșma alanında hem yüzey hem de yüzey altı topraklarının yarıdan fazlası ağır killi bünye sınıfında tespit edilmiştir (İdrisliönü, İdrisli, ve Cevizlidere seri toprakları gibi). Bu durum tarımsal açıdan havalanma, drenaj, geç tava gelme gibi bazı olumsuzluğa sebep olmaktadır. Çalışma alanının \%41 orana sahip kısmı için eğim herhangi bir sıkıntı yaratmamaktadır. Çalışma sahasındaki \%37.2 oranında (\%6-12 eğim sınıfı) bir alanda uygun sürüm teknikleri ve ürün deseni kullanılmak sureti ile tarımsal üretim yapılabilecektir. Ancak geriye kalan \%12 ve üzeri dik araziler için sınırlı tarımsal üretim yapılabilecektir. Bu alanların daha çok mera yahut ormanlı alan olarak kullanılması gerekmektedir. Çok sığ ve sığ derinliğe sahip topraklar özellikle eğimin fazla olduğu ve tarımsal faaliyetler için kullanılan alanlardır. $\mathrm{Bu}$ alanlarda toprakların yerinde kalmalarını sağlayabilmek amacıyla tarımsal faaliyetlerin yapılmasında özellikle toprak muhafaza tedbirlerinin (eğime dik sürüm vb.) alınması gerekmektedir.

\section{Teşekkür}

$\mathrm{Bu}$ çalışma, Ondokuz Mayıs Üniversitesi tarafından desteklenen PYO.ZRT.1904.17.048 no'lu proje kapsamında gerçekleştirilmiştir. Katkılarından dolayı teşekkür ederiz.

\section{Kaynaklar}

Adiloğlu, A. ve Adiloğlu, S., 2004. An investigation on nutritional problems of hazelnut (Corylus avellana) grown in acid soils of Turkey. Pakistan Journal of Biological Sciences, 7(8): 1433-1437.

Anonymous., 1990. Micronutrient, Assessment at the Country Level: An International Study. FAO, Soils Bulletin by Mikko Sillanpaa, Rome.
Anonymous., 1992. Procedures for collecting soil samples and methods of analysis for soil survey. Washington D.C. USA. Soil Survey Staff.

Arslan, E., Çaycl, G., Dengiz, O., Yüksel, M., Atikmen, Çiçek N., 2018. Toprakların bazı makro besin elementi içeriklerinin farklı tarımsal arazi kullanımları altında konumsal dağılımlarının belirlenmesi. Toprak Su Dergisi, 7(2): 28-37.

Arslan, H., 2012. Spatial and temporal mapping of groundwater salinity using ordinary kriging and indicator kriging: the case of Bafra Plain, Turkey. Agricultural Water Management, 113: 57-63.

Ateș, K. ve Turan, V., 2015. Some soil characteristics and the fertility status of agricultural soils in Bingöl central district. Türkiye Tarımsal Araştırmalar Dergisi, 2(2): 108-113.

Aydın, A., 2018. Sürdürülebilir Arazi Yönetimi İçin CBS Yardımıyla Toprak Veri Tabanı Oluşturulması. Yüksek Lisans Tez Çalışması, Ondokuz Mayıs Üniversitesi, Fen Bilimleri, Samsun.

Blake, G.R. ve Hartge, K.H., 1986. Bulk Density and particle density. Methods of Soil Analysis: Part 1-Physical and Mineralogical Methods (methods of soil an. 1), 363-375 pp.

Bouyoucos, G.J., 1962. Hydrometer Method Improved for Making Particle Size Analyses of Soils 1. Agronomy journal, 54(5): 464-465.

Bremner, J.M., Mulvaney, C.S.,1982. Nitrogen-Total. Methods of soil analysis. Part 2. Chemical and microbiological properties (methods of soil an. 2), 595-624 pp.

Çakıcı, H, Çiçekli, M., ve Arslan, H., 2012. Bağyurdu-izmir yöresi kiraz plantasyonlarının beslenme durumu. Ege Üniversitesi Ziraat Fak. Dergisi, 49(1): 7-15.

Çelik, P., Dengiz, O., 2018. Akselendi Ovası tarım topraklarının temel toprak özellikleri ve bitki besin elementi durumlarının belirlenmesi ve dağılım haritalarının oluşturulması. Türkiye Tarımsal Araștırmalar Dergisi, 5(1): 9-18.

Çimrin, K. M. ve Boysan, S., 2006. Van yöresi tarım topraklarının besin elementi durumları ve bunların bazı toprak özellikleri ile ilişkileri. Yüzüncü Yıl Üniversitesi Tarım Bilimleri Derg., 16(2): 105-111.

Çullu, M. A., 2012. Toprak etüt haritalama ve toprak yönetimi gerekliliği. Editör'den: 23 .

Ersoy, A., Yünsel, T., 2008. Assessment of lignite quality variables: a practical approach with sequential Gaussian simulation. Energy Sources, Part A: Recovery, Utilization, and Environmental Effects, 31(2): 175-190.

Feizizadeh, B. ve Blaschke, T., 2013. Land suitability analysis for Tabriz County, Iran: a multi-criteria 
evaluation approach using GIS. Journal of Environmental Planning and Manage, 56(1): 1-23.

Güçdemir, İ., 2006. Türkiye Gübreler ve Gübreleme Rehberi. TC TBK TAGEM Toprak ve Gübre Araştırma Enstitüsü Müdürlüğü Yayınları Genel Yayın No:231, Ankara.

Hagedorn, F., Mulder, J., Jandl, R., 2010. Mountain soils under a changing climate and land-use. Biogeochemistry, 97(1): 1-5.

Heuvelink, G. B., 2006. Incorporating process knowledge in spatial interpolation of environmental variables. 7th Inernational Symposium on Spatial Accuracy Assessment 32-47pp.

Jackson, M. L., 1958. Soil chemical analysis. Prentice-Hall, Inc.; Englewood Cliffs.

Keskin, H. ve Grunwald, S. 2018. Regression kriging as a workhorse in the digital soil mapper's toolbox. Geoderma, 326: 22-41.

Kirişçi, V., Keskin, M., Say, S., Keskin, S., 1999. Hassas uygulamalı tarım teknolojisi. Nobel Yay., 88: 186.

Klute, A. ve Dirksen, C., 1986. Hydraulic conductivity and diffusivity: Laboratory methods. Methods of Soil Analysis, 687-734 pp.

Lindsay, W. ve Norvel, W., 1978. Development of a DTPA as a soil response investigation of $\mathrm{Mn}+2$ complexation in natural and synthetic organics. Soil Science Society of America Journal, 46: 1137-1143.

Loue, A. 1968. Diagnostic petiolaire de prospection. Etudes Sur la Nutrition et la Fertilisation Potassiques de la Vigbe Societe Commerciale des Potasses d'Alsace Services Agroomiques: 31-41 pp.

Luo, H. ve He, X., 2011. An improved inverse distance weighted interpolation method for InSAR tropospheric delay error corrections. International Conference on Information Science and Technology, IEEE, 480-482 pp.

Mallants, D., Mohanty, B. P, Jacques, D., Feyen, J., 1996. Spatial variability of hydraulic properties in a multi-layered soil profile. Soil Science, 161(3): 167.

Mapedza, E., Wright, J., Fawcett, R., 2003. An investigation of land cover change in Mafungautsi Forest, Zimbabwe, using GIS and participatory mapping. Applied Geography, 23(1): 1-21.

Nelson, D. ve Sommers, L. E., 1982. Total carbon, organic carbon, and organic matter 1. Methods of soil analysis. Part 2. Chemical and microbiological properties (methods of soil an. 2 ), 539-579 pp.

Olsen, S.R., 1954. Estimation of available phosphorus in soils by extraction with sodium bicarbonate. United States Department of Agriculture; Washington.
Özyazıcı, M. A, Dengiz, O., Aydoğan, M., Bayraklı, B., Kesim, E., Urla, Ö., Ünal, E., 2016. Orta ve Doğu Karadeniz Bölgesi tarım topraklarının temel verimlilik düzeyleri ve alansal dağılımları.

Özyazici, M. A., Dengiz, O., Sağlam, M., Erkoçak, A. Türkmen, F., 2017. Mapping and assessment-based modeling of soil fertility differences in the central and eastern parts of the Black Sea region using GIS and geostatistical approaches. Arabian Journal of Geosciences, 10(45):2-9.

Rhoades, J., 1982. Cation Exchange Capacity 1. Methods of soil analysis. Part 2. Chemical and microbiological properties(methods of soil an.2), 149-157 pp.

Sağlam, M., 2013. Çok değişkenli istatistiksel yöntemler ile toprak özelliklerinin gruplandırılması. Toprak Su Dergisi, 2(1): 7-14.

Sharma, P., Sood, A., Setia, R, Tur, N., Mehra, D., Singh, H., 2008. Mapping of macronutrients in soils of Amritsar district (Punjab) A GIS approach. J. Indian Soc. Soil Sci, 56(1): 34-41.

Tarakçıŏlu, C., Yalçın, S., Bayrak, A., Küçük, M. ve Karabacak, H., 2003. Ordu yöresinde yetiștirilen fındık bitkisinin (Corylus avellana L.) beslenme durumunun toprak ve yaprak analizleriyle belirlenmesi. Tarım Bilimleri Dergisi, 9(1): 13-22.

Taşan, M., Demir, Y., 2017. Çeltik yetiştiriciliği yapılan arazilerde demir ve mangan içeriklerinin alansal dağılımının farklı enterpolasyon yöntemleri ile Belirlenmesi. Anadolu Tarım Bilimleri, 32(1): 64.

Thornthwaite, C.W., 1948. An approach toward a rational classification of climate. Geographical review, 38(1): 55-94.

Turan, M., Dengiz, O., Turan Demirağ, İ. 2018. Samsun İlinin Newhall Modeline Göre Toprak Sıcaklık ve Nem Rejimlerinin Belirlenmesi. Türkiye Tarımsal Araştırmalar Dergisi, 5(2): 131-142.

Tümsavaş, Z. ve Aksoy, E., 2008. Kahverengi Orman büyük toprak grubu topraklarının verimlilik durumlarının belirlenmesi. Uludağ Üniv Ziraat Fak Der, 22(1): 43-54.

Ülgen, A. N., Yurtsever, N., 1995. Türkiye gübre ve gübreleme rehberi. Tarım Orman ve Köyişleri Bakanlı̆̆ı Toprak ve Gübre Araştırma Enstitüsü Müdürlüğü.

Wilding, L., 1985. Spatial variability: Its documentation, accommodation and implication to soil surveys. Soil spatial variability. Workshop, 166-194pp.

Yıldız, N., Akbulut, Ö., Bircan, H., 1999. İstatistiğe giriş. Aktif Yayınevi, Erzurum, 359pp. 